\title{
IMPLEMENTASI MASLAHAH MURSALAH SEBAGAI ALTERNATIF HUKUM ISLAM DAN SOLUSI PROBLEMATIKA UMAT
}

\author{
Abu Yasid Adnan Quthni*
}

\begin{abstract}
In the approach of Islamic law, Maslahah mursalah is a proposition to establish a new problem that has not been explicitly mentioned in the main sources, the Qur'an and As-Sunnah, both accepted and rejected. Maslahah mursalah as an option for this legal proposition begins with the Passed away of the Prophet Muhammad SAW. Along with this happened, the revelation of the Qur'an has stopped coming down, and the words of the Prophet have stopped too. Meanwhile, problems continue to develop from time to time along with the development of the community itself. This is where the idea of Maslahah mursalah emerges as an option for the proposition of Islamic law. Please note, in the application, Maslahah mursalah is based on benefit. Looking at the main basis of this argument, understanding and knowing about the theory of benefit becomes a necessity in the use of maslahah as a proposition of Islamic law. Maslahah is a concept that departs from the main purpose of Islamic law, known as maqashid as-sharia. According to Imam As-Syatibi, the main orientation of maqashid as-sharia is to provide protection and protection against five things, namely religion, self, lineage, reason, and wealth. These five aspects are very fundamental things in life, so that damage to one aspect alone will cause extraordinary negative implications. Thus, maslahah is the main consideration in evaluating the value of benefits and harm from a problem that has just emerged in people's lives. An order to assess benefits and madharat, then weigh which one is greater, the benefits or the madharat (damage).
\end{abstract}

Keywords: Maslahah mursalah, law alternative, Islamic law

* Dosen Fak. Syariah Institut Ilmu Keislaman Zainul Hasan Genggong Kraksaan 


\section{Pendahuluan}

Dewasa ini, sejumlah persoalan baru yang tidak ditemukan dalam zaman Rasulullah saw mulai bermunculan. Persoalan baru ini, sejatinya juga dialami para sahabat pasca peninggalnya Rasulullah saw. Dalam hal ini, para sahabat dihadapkan pada persoalan yang mengharuskan mereka berijtihad dengan mengidentifikasi persoalan dengan melihat teks Alquran, jika tidak ditemukan maka langkah selanjutnya mencari dalam hadis-hadis nabi saw. Jika persoalan belum selesai sampai tahap tersebut maka ditempuh musyawarah untuk melakukan ijtihad dengan ra'yu yakni dengan cara qiyas dan mashlahah yang intinya adalah mengidentifikasi hukum suatu perbuatan manusia yang tidak memiliki keterangan dari teks-teks keagamaan. ${ }^{1}$

Sehingga masa sepeninggal nabi saw, sejatinya merupakan awal permasalahan dalam perkembangan hukum Islam. Persoalan hukum yang dimunculkan oleh perubahan zaman dan perkembangan teknologi serta perubahan sosial terus mengemuka sebagai dinamika kehidupan manusia di dunia sepanjang masa. Ayat-ayat Alquran dan hadis-hadis nabi perlu penalaran dan kajian lebih mendalam untuk menyelesaikan permasalahan ummat. Solusi penyelesaian dalam bentuk ijtihad merupakan proses berfikir rasional secara optimal dalam menetapkan hukum Islam dengan tetap mengacu pada kedua sumber hukum yaitu Alquran dan hadis, agar dapat ditemukan jawaban atas berbagai persoalan yang muncul di tengah-tengah ummat. Apalagi hukum Islam sebenarnya sudah berlaku sejak kedatangan pertama Islam, di mana stigma hukum yang dikategorikan menjadi hukum adat, hukum Islam. ${ }^{2}$ Lalu bagaimana jika ada suatu permasalahan muncul ditengah kehidupan masyarakat tidak ditemukan dalam teks Al-qur'an dan assunnah?

Nah, maslahah muslahah ini merupakan salah satu metode penetapan hukum yang sangat efektif dalam merespon, menyikapi, serta memberikan solusi ketika terjadi permasalahan yang dalam nash Alqur'an dan as-Sunnah tidak ditemukan. Maslahah mursalah merupakan

1 Muhammad Abu Zahrah,Tarikh al-Mazahib al-Islamiyh (al- Qahirah: Dar alFikr al-'Arabi, t.th), h. 16

2 Islam, M. H. (2018). ISLAMIC LAW IN INDONESIA (Tradition, Thought, Political Law and Legal Products). As-Syari'ah: Jurnal Hukum Islam, 4(1), 31-50. 
salah satu metode istinbath yang bisa dipergunakan oleh ushuliyyin (pakar metodologi hukum islam) ketika dihadapkan dengan suatu kasus baru yang tidak ada dasar hukumnya di dalam al-Quran maupun al-Hadis. Semisal persoalan hukum pencatatan pernikahan. Hukum pencatatan pernikahan tidak ditemukan aturan mainnya didalam al-Quran maupun al-Hadist, padahal persoalan ini sangat penting untuk dicarikan solusinya. Pernikahan yang tidak dicatatkan ke KAU sangat rentan sekali menimbulkan masalah ketika suami tidak mau melaksanakan tanggung jawabnya. Hal ini terjadi karena pernikahan yang terjadi dianggap tidak sah dimata hukum walaupun sebenarnya sah dimata agama. Sehinga ketika istri ingin menuntut hak melalui pintu penggadilan tidak bisa dilakukan. Oleh karena itu, untuk meminimalisir efek negatif yang timbul dari pernikahan yang tidak dicatatkan ke KAU, para uluma' memberikan fatwa bahwa persoalan pencatatan pernikahan hukumnya mubah berdasarkan maslahah.

Namun tentunya dalam ber-istinbath mengunakan Maslahah mursalah perlu ada standarisasi yang jelas, karena bila tidak dibatasi dengan aturan yang ketat sangat dihawatirkan akan timbul hukum yang bertentangan dengan tujuan pembentukan hukum islam itu sendiri. Jangan sampai hukum yang diputuskan nanti bukannya mewujudkan kemaslahatan bagi umat manusia malah menimbulkan kemafsadatan setelah hukum tersebut diterapkan.

Hal ini sangat dimungkinkan terjadi, karena pembentukan hukum yang didasarkan pada maslahah sangat rentan membuka pintu hawa nafsu bila dilakukan dengan sembarangan. Terkadang tanpa sadar ketika ber-istinbath menggunakan maslahah sering terbayang dalam benak ushuliyyin (pakar metodologi hukum islam) mafsadah yang terjadi sebagai bentuk dari maslahah. Sehinga hukum yang diputuskan jauh dari nilai-nilai kebenaran. Selain itu penyebab lainnya adalah maslahah sering diidentikan dengan kebaikan/kemanfaatan.

Sementara kebaikan/ kemanfaatan dalam persepsi orang berbedabeda antara satu sama lainnya. Suatu persoalan bisa saja diangap baik oleh seseorang tetapi bisa diangap tidak baik oleh orang lain. Perbedaan ini terkadang dilatarbelakangi oleh perbedaan pemikiran atau kepentingan. Oleh karena itu, pembukaan pintu pembentukan hukum berdasarkan mutlaknya kemaslahatan tanpa mengikuti syarat-syaratnya 
dikhawatirkan akan membuka pintu kemafsadatan.

\section{Pengertian Maslahah mursalah}

Maslahah mursalah terdiri dari dua kata, yaitu kata maslahah dan mursalah. Dilihat dari sisi etimologis, kata maslahah merupakan bentuk masdar (adverb) yang berasal dari fi'il (verb), yaitu صلح (saluha). Adapun dilihat dari sisi bentuknya, disamping kata maslahah merupakan bentuk adverb, ia juga merupakan bentuk ism (kata benda) tunggal (mufrad, singular) dari kata masâlih (jama', plural). ${ }^{3}$ Kata maslahah ini telah diserap ke dalam bahasa Indonesia menjadi maslahat, begitu juga kata manfaat dan faedah. Dengan demikian, kata mashlahah juga diartikan dengan al-shalah yaitu kebaikan atau terlepas darinya kerusakan. ${ }^{4}$ Jadi, setiap yang mengandung manfaat patut disebut maslahah. Ungkapan bahasa Arab juga menggunakan maslahat dalam arti manfaat atau perbuatan dan pekerjaan yang mendorong serta mendatangkan manfaat kepada manusia. ${ }^{5}$

Sedangkan dalam arti umum, maslahah diartikan sebagai segala sesuatu yang bermanfaat bagi manusia, baik dalam arti menarik atau menghasilkan, seperti menghasilkan keuntungan atau kesenangan, atau dalam arti menolak atau menghindarkan seperti menolak kemudaratan atau kerusakan. Jadi, setiap yang mengandung manfaat patut disebut maslahat meskipun manfaat yang dimaksud mengandung dua sisi, yaitu mendatangkan kebaikan dan menghindarkan bahaya atau kerusakan disisi lain. ${ }^{6}$

Maslahat secara terminologi, terdapat beberapa definisi yang dikemukakan oleh ulama usul fikih. Rumusan definisi maslahat antara lain dikemukakan oleh al-Tufi, al-Gazali, al-Syatibi, al- Kawarizmi, al-'Izz al-Din bin 'Abd al-Salam, al-Taraki, dan al- Rabi'ah. Al-Tufi (L $675 \mathrm{M}-716 \mathrm{M})$ menjelaskan bahwa maslahat dapat ditinjau dengan pendekatan adat, selain pendekatan syariat. Dalam pendekatan adat,

3 Ibn al-Manzûr, Lisân al-'Arabal-Muhît (Beirut: Dâr al-Fikr, 1972), Juz II, hlm.348;

4 Rahmad Syafi'i, ilmu usul fiqh, (Bandung:Pustaka Setia, 2007), h, 117

5 Abdul Aziz Dahlan, dkk, Ensiklopedi Hukum Islam, Jilid IV (Jakarta: PT Ichtiar Baru van Hoeve, 2001), h. 143.

6 Amir Syarifuddin, Ushul Fiqh, Jilid II (Jakarta: Kencana, 2009) h. 345 
maslahat berarti sebabyang mendatangkan kebaikan dan manfaat, seperti perdagangan yang dapat mendatangkan keuntungan. Sedangkan dalam pengertian syariat, maslahat adalah ibarat dari sebab yang membawa kepada syariat dalam bentuk ibadah atau adat. Definisi ini dipandang sesuai dengan definisi al-Gazali bahwa maslahat dalam artian syariat sebagai sesuatu yang dapat membawa kepada tujuan syariat itu sendiri. ${ }^{7}$

Al-Gazali (L 1058 M - W 1111 M) mendefinisikan bahwa menurut asalnya maslahat berarti sesuatu yang mendatangkan manfaat dan menghindarkan mudarat (bahaya/kerusakan). Namun, hakikatnya adalah al-muhafazah 'ala maqsud al-syar'i (memelihara tujuan syara'). Sementara tujuan syara' dalam menetapkan hukum terdiri dari lima unsur, yaitu memelihara agama, jiwa, akal, keturunan, dan harta. Maka semua hal yang memenuhi unsur tersebut disebut sebagai maslahat, dan sebaliknya hal-hal ynag menyalahi unsur tersebut disebut mafsadat. ${ }^{8}$

Al-Syathibi (W 1388 M) dalam al-Muwafaqat menjelaskan definisi maslahat dari dua segi, yaitu dari segi terjadinya maslahat dalam kenyataan, berarti sesuatu yang kembali kepada tegaknya kehidupan manusia, sempurna hidupnya, tercapai apa yang diinginkan oleh syahwat dan akalnya secara mutlak. Sementara 'Izz al-Din 'Abd al-'Aziz bin 'Abd al-Salam (L 1181 M -W 1262 M) dalam kitabnya Qawa'id al-Ahkam fi Masalih al-Anam memaparkan bahwa maslahat memiliki dua bentuk makna, yaitu bentuk hakiki dan bentuk majasi.

Maslahat dalam bentuk hakiki diartikan dengan kesenangan dan kenikmatan, sedangkan maslahat dalam bentuk majasi diartikan dengan sebab-sebab yang mendatangkan kesenangan dan kenikmatan tersebut. Pemaknaan ini didasarkan pada pandangan dasar bahwa pada prinsipnya manfaat memiliki empat bentuk, yaitu: kelezatan dan sebabsebabnya serta kesenangan dan sebab-sebabnya. ${ }^{9}$

Al-Taraqi (L 1917 M - W 1979 M) menguraikan bahwa maslahah adalah segala sifat yang terdapat dalam pengaturan hukum bagi muallaf dalam bentuk penarikan manfaat dan penolakan terhadap segala

7 Najm al- Din al-Tufi, Risalah fi Ri'ayah al-Maslahah (Libanon: al-Dar alMasdariyyah al-Lubnaniyyah, 1993), h. 25

8 Abu Hamid Muhammad Ibn Muhammad al-Gazali, al-Mustasfa (Bairut: Dar al-Kutub al 'Ilmiyyah, 1993), h. 174

9 Izz al-Din 'Abd al-Aziz bin 'Abd al-Salam al- Dimasyqi, Qawa'id al-Ahkam fi Masalih al-Anam, Juz I (al-Qahirah: Muqtabah al-kulliyat al-azhariyah,1991), h.14 
macam yang menyebabkan kerusakan. ${ }^{10} \mathrm{Al}$-Rabi'ah menyatakan bahwa maslahat adalah segala macam manfaat yang dimaksudkan oleh Sang Pembuat Syariat terhadap hamba-Nya untuk menjaga agama, jiwa, akal, keturunan dan harta mereka dan menolak apa saja yang mengancam atau menghilangkannya. ${ }^{11}$

Menurut al-Buthi, dalam kitab Dhawabit al- Mashalah fi al-Syari'ah al-Islamiyah, karakteristik maslahah yang berbeda dengan maslahah atau manfaat dalam artian umum adalah (a) waktu yang memengaruhi maslahat dan mafsadat tidak terbatas hanya di dunia saja, tetapi merupakan gabungan antara dunia dan akhirat; (b) nilai maslahat tidak terbatas pada kelezatan meterial semata, namun ia bersumber dari kebutuhan jasad dan ruh manusia dan (c) kemaslahatan agama merupakan fundamental dan harus didahulukan dari kemaslahatan lainnya. Untuk manjaga dan mempertahankan kelestarian pengamalan ajaran agama, Allah menyuruh hambanya mengorbankan apa saja yang dimilikinya, termasuk jiwa dan hartanya. Karena itu, semua kegiatan yang dilakukan dalam pemenuhan kepuasan hidup di dunia ini, jangan sampai ia mengurangi atau mengecilkan pengamalan syariat. ${ }^{12}$

Walaupun para ulama berbeda-beda dalam memandang Maslahah mursalah, hakikatnya adalah satu, yaitu setiap manfaat yang didalamnya terdapat tujuan syara' secara umum, namun tidak terdapat dalil yang secara khusus menerima atau menolaknya. ${ }^{13}$

Hal yang membedakan antara Qiyas dan Maslahah mursalah adalah Qiyas berangkat dari illat (alasan utama suatu nash) sedangkan Maslahah mursalah berangkat dari hikmah. Hikmah adalah perbuatan yang arif yang mempunyai manfaat syari'ah secara sosial. Contoh dalam hal dibolehkannya pemerintah melakukan intervensi pasar jika harga yang terjadi dipasaran terjadi distorsi. Maslahah mursalah dalam beberapa literatur ada yang menyebutnya "munasibmursal", juga ada yang menamainya dengan "al-Istishlah" dan "al-isti'dal al-mursal". 2.

${ }^{10}$ Sa'ad bin Nasir al-Syassyari, al-Maslahah 'inda al- Hanabilah (t.tp.:t.p.,t.th.), h.

${ }^{11}$ Ibid, h.3

12 Jalaluddin Abdurrahman, al-Mashalih al-Mursalah wa Makanatuha di al-Tasyri', Mesir,Dar al-Kitab al-Kitab al-Jami'i, 1983, hal. 44-57

13 Rachmat Syafe'i, Ilmu Ushul Fiqh, (Bandung, CV Pustaka Setia, 1998) Cet. IV, hal. 119 
Tentunya, pengertian maslahah ini bertentangan dengan pengertian sebagaian filosof Barat. Menurut mereka, maslahah adalah sebuah manfaat untuk menuju kenikmatan, atau menolak bahaya di dunia semata. Sebab, segala sesuatu di muka bumi ini baik berupa kebajikan atau kejahatan tergantung pada kesepakatan bersama umat manusia. Karena memandang manusia sebagai subjek yang bisa menentukan standar nilai perbuatan mereka (baik/jelek). Epicurus ${ }^{14}$ mengatakan: "maslahah itu bersifat relatif dan subjektif, tergantung individu seseorang, tanpa memandang dampak yang ditimbulkan”. Pola pikir seperti ini berpengaruh kuat pada masyarakat Eropa, sehingga melahirkan ideide seperti: HAM, persamaan hak, dan lain-lain. Mereka berasumsi bahwa akal manusia tidak perlu lagi sesuatu yang lain (agama) dalam menentukan maslahah.

\section{Penetapan Syarat Maslahah mursalah Bisa Jadi Pijakan Hukum Islam}

Dalam setiap pengambilan suatu hukum, penetapan suatu syarat menjadi sesuatu yang niscaya agar dalam pengambilan suatu hukum bisa sesuai dengan spirit yang diharapkan. Dalam permasalahan Maslahah mursalah adalah bagaimana output yang dihasilkan tidak bertentangan dengan nash di dalam Al-qur'an dan as-sunnah. Imam malik sebagai salah satu ulama penggagas Maslahah mursalah menetapkan sejumlah syarat sebagai berikut. ${ }^{15}$ Pertama, harus memiliki persesuaian antara maslahat yang dipandang sebagai sumber dalil yang berdiri sendiri dengan tujuan-tujuan syari'at (maqashid as-syari'ah).

Dengan adanya persyaratan ini berarti maslahat tidak boleh menegaskan sumber dalil yang lain, atau bertentangan dengan dalil yang qat'i. Akan tetapi harus sesuai dengan maslahat-maslahat yang memang ingin diwujudkan oleh syari'. Misalnya, jenis maslahat itu tidak asing, meskipun tidak diperkuat dengan adanya dalil khas. Sedangkan

${ }^{14}$ Epicurus (341 SM.-271 M.) filosof Yunani, kemudian pemikiran ini diadopsi oleh filosof modern, sepertiThomas Hobbes (1588-1679 M.). diakses pada Tanggal 10 Februari 2018 di https://muhammadunaslam.wordpress.com/2010/06/21/maslahahdalam-islam/.

${ }^{15}$ Muhammad Abu Zahrah, Ushul Fiqh, Terj. Saefullah Ma'shum, dkk.,(Jakarta, PT Pustaka Firdaus; 1994) Cet II, hal. 427. 
syarat kedua adalah maslahat itu harus masuk akal (rationable), mempunyai sifat-sifat yang sesuai dengan pemikiran yang rasional, dimana seandainya diajukan kepada kelompok rasionalis akan dapat diterima. Dan yang ketiga adalah penggunaan dalil maslahat ini adalah dalam rangka menghilangkan kesulitan yang terjadi (raf'u haraj lazim). Dalam pengertian, seandainya maslahat yang dapat diterima akal itu tidak diambil, niscaya manusia akan mengalami kesulitan. Sebagaimana surat al-Hajj ayat 78

"Dan Dia sekali-kali tidak menjadikan untuk kamu dalam agama suatu kesempitan"

Dan al-Baqarah ayat 185 ,

"Allah menghendaki kemudahan bagimu, dan tidak menghendaki kesukaran bagimu"

Syarat-syarat di atas adalah syarat-syarat yang masuk akal yang dapat mencegah penggunaan sumber dalil ini (Maslahah mursalah) terserabut dari akarnya (menyimpang dari esensinya) serta mencegah dari menjadikan nash-nash tunduk kepada hukum-hukum yang dipengaruhi hawa nafsu dan syahwat dengan Maslahah mursalah.

Sedangkan menurut ulama Hanafiyah, untuk menjadikan Maslahah mursalah sebagai dalil disyaratkan maslahah tersebut berpengaruh terhadap hukum. Artinya ada ayat, hadis atau ijma' yang menunjukkan bahwa sifat yang ditunjuk sebagai kemaslahatan itu merupakan suatu illat (motivasi hukum) dalam penetapan suatu hukum, atau jenis hukum yang menjadi sifat motivasi hukum tersebut dipergunakan oleh nash sebagai motivasi suatu hukum. ${ }^{16}$

Misal sifat yang berpengaruh terhadap hukum tersebut adalah Rasulullah pernah ditanya tentang status sisa makanan kucing, apakah termasuk najis atau tidak. Keberadaan kucing yang selalu berada di

${ }^{16}$ Ma'ruf Amin, Fatwa dalam Sistem Hukum Islam (Jakarta: elSAS, 2011) h. 160. Tentang pandangan ulama Hanafiyah terhadap maslahah mursalah terdapat beberapa pendapat yang berbeda. Menurut al-Amidi sebagaimana dikemukakan Amir Syarifuddin, banyak ulama yang beranggapan bahwa ulama Hanafiyah tidak mengamalkannya. Namun menurut Ibn Qudamah, sebagian dari ulama Hanafiyah menggunakannya. Pandangan Ibn Qudamah ini agaknya lebih diperpegangi karena kedekatan metode maslahah mursalah dengan metode istihsan yang popular di kalangan ulama Hanafiyah. Amir Syarifuddin. Ushul Figh, h. 358 
rumah merupakan sifat yang menjadikan mereka bersih atau suci. Sifat yang menjadi motivasi hukum dalam hadis ini jelas yaitu thawwaf (hewan yang senantiasa berada di rumah, tidur di rumah dan sulit memisahkannya.

Berdasarkan sifat ini maka hukum sisa makanan kucing tidak najis. Thawwaf merupakan motivasi dan thaharah (suci) untuk menghindari kesulitan dari orang-orang yang memelihara kucing di rumahnya. Dalam konteks ekonomi, contoh jenis sifat yang dijadikan motivasi dalam suatu hukum adalah rasulullah saw melarang pedagang menghambat petani di perbatasan kota dengan maksud untuk membeli hasil pertanian mereka sebelum petani memasuki pasar. Larangan ini dimaksudkan untuk menghindarkan kemudharatan bagi petani dengan terjadinya penipuan harga oleh para pedagang yang membeli hasil pertanian tersebut di batas kota.

Sifat yang membuat larangan ini adalah adanya kemudaratan yang mempengaruhi hukum jual beli seperti yang dilakukan oleh pedagang tersebut. Jenis kemudaratan ini juga ada dalam masalah lain, seperti masalah dinding rumah yang hampir rubuh ke jalan, karena kondisi itu bisa memberi mudarat bagi orang lain.

Menurut ulama Hanafiyah kemudaratan petani dalam jual beli di atas sama dengan kemudaratan dinding yang hampi rubuh. Karenanya motivasi hukum terhadap dinding dapat dianalogikan dengan motivasi hukum dalam jual beli di atas. ${ }^{17}$ Dengan demikian, menurut Hanafiyah, menghilangkan kemudaratan termasuk dalam konsep maslahah mursalah dan dapat dijadikan sebagai salah satu metode penetapan hukum dengan syarat sifat kemaslahatan itu terdapat dalam nash atau ijma' dan jenis kemaslahatan itu sama dengan jenis sifat yang didukung oleh nash atau ijma' dan ulama Malikiyah menerima Maslahah mursalah sebagai dalil menetapkan hukum. Karena bagi mereka Maslahah mursalah merupakan induksi dari logika sekumpulan nash bukan dari nash yang rinci seperti qiyas. Misalnya Rasulullah saw bersabda dalam masalah naiknya harga barang di pasar. Beliau sebagai penguasa ketika itu tidak berhak campur tangan dalam masalah harga karena perbuatan campur tangan itu merupakan suatu yang zalim. Hal ini sebagaimana dijelaskan dalam sebuah hadis.

${ }^{17}$ Ibid, h. 161 
"Suatu ketika orang-orang berseru kepada Rasulullah saw. Menyangkut penetapan harga, "Wahai Rasulullah saw. Harga-harga naik, tentukanlah harga untuk kami." Rasulullah lalu menjawab : "Allahlah yang sesungguhnya Penentu harga, Penahan, Pembentang dan Pemberi rizki. Aku berharap agar bertemu kepada Allah tidak ada seorangpun yang meminta kepadaku tentang adanya kezaliman dalam urusan darah dan harta." (HR. Abu Daud). ${ }^{18}$

Menurut ulama Malikiyah hadis Rasulullah saw tersebut berlaku ketika supply sedikit sedangkan demand banyak, sehingga kenaikan adalah wajar. Akan tetapi jika kenaikan tersebut bukan disebabkan excess demand tetapi karena ulah pedagang itu sendiri maka ulama Malikiyah membolehkan pemerintah turut campur dalam penetapan harga dengan pertimbangan "kemaslahatan" konsumen. Sedangkan untuk menjadikan Maslahah mursalah sebagai dalil penetapan hukum, ulama Hanafiyah menetapkan persyaratan yaitu:

1. Kemaslahatan tersebut sesuai dengan kehendak syara' dan termasuk ke dalam kemaslahatan yang didukung nash secara umum.

2. Kemaslatan tersebut bersifat rasional dan pasti, bukan sekedar perkiraan sehingga hukum yang ditetapkan melalui Maslahah mursalah itu benar- benar memberikan manfaat dan menghindari kemudaratan

3. Kemaslahatan tersebut menyangkut orang banyak, bukan kepentingan priibadi atau kelompok kecil tertentu. ${ }^{19}$

\section{Ruang Lingkup Maslahah Mursalah}

Dalam pengambilan hukum melalui Maslahah mursalah, selain yang berlandaskan pada hukum syara' secara umum, juga harus diperhatikan adat dan hubungan antara satu manusia dengan yang lainnya, dengan kata lain Maslahah mursalah hanya meliputi kemaslahatan yang berhubungan dengan muamalah. ${ }^{20}$

Sedangkan masalah ibadah bukanlah termasuk dalam lapangan

${ }^{18}$ Abu Daud, Shahih Sunan Abu Dawud, Jilid 2 (Riyad: Maktabah al-Ma'arif, 1998), h. 362. No. hadis 2994

${ }^{19}$ Ma'ruf Amin, Fatwa dalam Sistem Hukum Islam, h. 163

${ }^{20}$ Rahmad Syafii, Op Cit, hal . 121. 
tersebut. Alasannya karena Maslahah mursalah didasarkan pada pertimbangan akal tentang baik buruk suatu masalah, sedangkan akal tidak dapat melakukan hal itu untuk masalah ibadah. Segala bentuk perbuatan ibadah ta'abuddi dan tawqifi, artinya kita hanya mengikuti secara apa adanya sesuai dengan petunjuk syar'i dalam nash, dan akan sama sekali tidak dapat mengetahui kenapa demikian. Misalnya mengenai shalat dhuhur empat rakaat dan dilakukan setelah tergelincir matahari, tidak dapat dinilai akal apakah itu baik atau buruk. Diluar wilayah ibadah, meskipun diantaranya ada yang tidak dapat diketahuialasan hukumnya, namun secara umum bersifat ta'aqquli (rasional) dan oleh karenanya dapat dinilai baik dan buruknya oleh akal. ${ }^{21}$

\section{Klasifikasi Maslahah Menurut Ulama Ushul Fiqh}

Untuk memudahkan klasifikasi maslahah sebagai acuan dalam pengambilan hukum Islam, para ahli ushul fiqih membaginya menjadi beberapa bagian. Pertama, maslahat ditinjau dari segi kualitas dan kepentingan maslahat, kemudian kedua maslahat ditinjau dari segi subtansi maslahat, Ketiga adalah maslahat dilihat dari perubahan maslahat, dan ke-empat adalah maslahat ditinjau dari legalitas formal. Untuk Maslahat yang pertama (maslahat ditinjau dari segi kualitas dan kepentingan maslahat ) ulama usul fiqh membagi menjadi tiga macam yaitu:

1. Maslahah al-Dharuriyyah, yaitu kemaslahatan yang berhubungan dengan kebutuhan pokok manusia di dunia dan di akhirat. Kemaslahatan seperti ini ada lima, yaitu memelihara agama, jiwa, akal, keturunan, dan memelihara harta. Kelima kemaslahatan ini di sebut al-mashalil al-khamsah.

2. Mashlahah al-Hajiyah, yaitu kemaslahatan yang dibutuhkan dalam menyempurnakan kemaslahatan pokok (mendasar) sebelumnya yang berbentuk keringanan untuk mempertahankan dan memelihara kebutuhan dasar manusia. Misalnya dalam mu'amalah di bolehkan melakukan jual beli pesanan.

3. Mashlahah al-Tahsiniyyah, yaitu kemaslahtan yang sifatnya pelengkap berupa keleluasaan yang dapat melengkapi kemaslahatan

${ }^{21}$ Amir Syarifuddin, Op Cit, hal . 340 
sebelumnya. Misalnya di anjurkan memakan makanan yang bergizi dan berpakaian yang bagus-bagus. ${ }^{22}$

Selanjutnya, Ulama ushul fiqh membagi maslahah berdasarkan kandungan maslahat atau hubungannya dengan umat atau individu tertentu membagi dua macam maslahat. Pertama, al-maslahah al-âmmah atau al-maslahah al-kulliyyah dan al-maslahah al-khassah atau al-maslahah al-juz'iyyah. Al-Maslahah al-ammah atau al-maslahah al-kulliyyah, yaitu kemaslahatan umum yang menyangkut kepentingan orang banyak. Contoh, menjaga Alquran agar tidak hilang dan berubah dengan cara menjaga para penghafal Alquran dan mushaf, menjaga hadis-hadis nabi saw. agar tidak tercampur dengan hadis palsu, dan maslahat lainnya yang menyangkut orang banyak. ${ }^{23}$

Kedua, Al-maslahah al-khazzah atau al-maslahah al-juz'iyyah adalah maslahah yang bersifat individu atau kepentingan segelintir orang. maslahat ini terdiri dari tiga pembagian, yaitu: qath'iyyah, zanniyyah, dan wahmiyyah. Qath'iyyah adalah yang ditunjukkan oleh dalil yang bersifat absolute dan tidak dapat ditakwil lagi. Zanniyah adalah yang ditunjukkan oleh dalil bersifat relatif, seperti yang ditunjukkan dalam hadis: (hendaklah seorang hakim tidak memutuskan suatu perkara dalam keadaan marah). Wahmiyyah adalah berdasar pada adanya tandatanda maslahat dan kebaikan, namun ternyata mendatangkan mudarat.

Lalu bagaimana pandagang ulama ushul memandang maslahat berdasarkan perubahan maslahat?. Dalam hal ini, Mustafa al-Syalabi, seorang guru besar ushul fiqh di Universitas al-Azhar Kairo, membagi maslahat berdasarkan perubahan maslahat menjadi dua, yaitu (1) almaslahah al-sabitah, yaitu ke- maslahatan yang bersifat tetap dan tidak akan berubah sampai akhir zaman seperti kewajiban ritual ibadah, seperti salat, puasa, zakat, dan haji dan (2) al-maslahah al-mutagayyirah, yaitu kemaslahatan yang berubah-ubah sesuai dengan perubahan tempat, waktu, dan subjek hukum. Kemaslahatan seperti ini berkaitan dengan permasalahan muamalah dan adat kebiasaan seperti dalam masalah makanan yang berbeda-beda antara satu daerah dan daerah lainnya. menurut Mustafa al-Syalabi, pembagian ini penting dalam kaitannya

${ }^{22}$ Nasrun Haroen, ushul fiqih, (Ciputat : PT Logos Wacana Imu , 1997) hal. 115116

${ }^{23}$ Muhammad Tahir bin Asyur, Maqasid al-Syari'ah al-Islamiyah, hal. 313 
untuk memberikan gambaran batasan kemaslahatan yang bisa berubah dan kemaslahatan yang tidak berubah. ${ }^{24}$

Untuk Maslahat berdasarkan konteks legalitas formal. Maslahat ini terdiri tiga macam. Pertama al-maslahah al-mu'tabarah, Kedua, almaslahah al-mulgah, dan al-maslahah al-maskut 'anha. ${ }^{25} \mathrm{Al}$-maslahah almu'tabarah adalah maslahah yang mendapatkan petunjuk dari syari', baik secara langsung maupun tidak langsung, bahwa ada maslahat yang menjadi alasan dalam menetapkan sebuah hukum. ${ }^{26}$

Al-maslahah al-mulgah atau maslahat yang ditolak adalah maslahat yang pada dasarnya dianggap baik oleh akal, tetapi tidak diperhatikan oleh syariat, bahkan ada petunjuk syariat yang menolaknya. ${ }^{27} \mathrm{Al}$ maslahah al-maskut 'anha, yaitu maslahat yang didiamkan oleh syariat dimana keberadaannya tidak didukung oleh syariat dan tidak pula dibatalkan atau ditolak oleh syariat dengan dalil yang terperinci. Almaslahah al-mursalah atau oleh beberapa ulama lain diberi istilah berbeda, misalnya al-munasib al-mursal, istislah dan istidlal al-mursal yaitu maslahat yang tidak diakui oleh dalil syariat atau nas secara spesifik, akan tetapi didukung oleh sejumlah makna nas. ${ }^{28}$

Perlu diketahui, dalam kontek legalitas formal, maslahat terbagi tiga yaitu al-maslahah al-mu'tabarah, al-maslah al-mulgat, dan al-maslahah al-mursalah. Mayoritas ulama sepakat untuk menggunakan maslahat mu'tabarah, namun tidak menempatkannya sebagai dalil dan metode yang berdiri sendiri. Ia digunakan karena adanya petunjuk syariat yang mengakuinya, baik secara langsung atau tidak langsung. Legitimasi akan maslahat dalam bentuk ini sebagai metode ijtihad karena adanya petunjuk syariat tersebut, sehingga ia diamalkan dalam konteks pengamalan qias. $^{29}$

Ulama sepakat untuk menolak menggunakan maslahat mulgat

${ }^{24}$ Abd. Aziz Dahlan ,dkk., Ensiklopedia Hukum Islam, Jilid IV, h. 1145.

${ }^{25}$ Abd al-Karim Zaidan, al-Wajiz fi Usul al-Fiqh (Bairut: Muassasah al-Risalah, 1987), h. 276.

${ }^{26}$ Abd al-Wahhab Khallaf, Ilm Usul al-Fiqh wa Khulasah Tarikh al-Tasyri' (Mesir: Matba'ah al-Madani, t.th.), h. 83.

${ }^{27}$ Abu Hamid Muhammad bin Muhammad al-Gazali, al-mustafa, h.174

${ }^{28} \mathrm{Badr}$ al-Din Muhammad bin 'Abdullah al-Zarkasyi, al-Bahr al-Muhit fi Usul al-Fiqh, Juz VIII (t.tp.: Dar al-Kutaibi, 1994), h. 83.

${ }^{29}$ Amir Syarifuddin, Usul Fiqh, Jilid II, h. 357. 
dalam berijtihad, karena meskipun mengandung maslahat menurut akal dan sejalan dengan prinsip dan tujuan syariat, namun bertentangan dengan dalil yang jelas adanya. Menurut mayoritas ulama, bila terjadi pertentangan antara nas dengan maslahat, maka nas harus didahulukan. Sama halnya dengan maslahat mulgat, maslahat garibah juga tidak dapat dijadikan landasan dalam menetapkan sebuah hukum, karena tidak ditemukan dalam praktik. ${ }^{30}$

\section{Pro Kontra Tentang Kehujahan Maslahah Mursalah}

Sebagai salah satu metode pengambilan hukum dalam agama Islam yang paling akhir-sejumlah ulama masih terdapat pro dan kontra dalam permasalahan pengambilan hujjah melalui Maslahah mursalah. Menurut mayoritas ulama, dengan mengutip dalil QS al-Anbiya'/21: 107 yang terjemahnya "tiadalah kami mengutus Engkau (Muhammad), melainkan untuk (menjadi) rahmat bagi semesta alam". Menunjukkan bahwa Rasulullah saw. tidak akan menjadi rahmat apabila bukan dalam memenuhi kemaslahatan umat manusia. Ayat- ayat Alquran dan hadis nabi saw seluruhnya dimaksudkan untuk mencapai kemaslahatan manusia, baik di dunia maupun di akhirat. Oleh karena itu, memberlakukan maslahat terhadap hukum-hukum lain yang juga mengandung kemaslahatan adalah sah.

Selain ayat yang disebutkan diatas, adanya taqrir (pengakuan/ legitimasi ) dari nabi saw atas penjelasan Mu'az bin Jabal yang akan menggunakan ijtihad bi al-ra'yi jika tidak menemukan ayat Alquran dan sunah nabi saw dalam rangka menyelesaikan sebuah kasus hukum. Penggunaan ijtihad ini mengacu pada penggunaan daya nalar atau sesuatu yang dianggap maslahat. Nabi saw sendiri pada waktu itu tidak membebani Mu'az untuk mencari dukungan nas. Hadist tersebut arti isi kandungannya sebagai berikut:

"Bahwasanya Rasulullah shallaallaahu 'alaihi wasallam mengutus Muad ke Yaman bersabda: "bagaimana engkau akan menghukum apabila datang kepadamu satu perkara?" Ia (Mu'adz) menjawab "saya akan menghukum dengan kitabullah". Sabda Beliau: Bagaimana jika tidak terdapat di kitabullah?". Ia menjawab: saya akan menghukum dengan

${ }^{30}$ Abdul Aziz Dahlan, dkk, Ensiklopedi Hukum Islam, Jilid IV, h, 1146 
sunnah Rasulullah". Beliau bersabda: Bagaimana jika tidak terdapat dalam sunnah Rosulullah?". Ia menjawab:” say berijtihad dengan pikiran saya dan tidak akan mundur..." Hadis ini diriwayatkan oleh Abu Daud dalam sunannya nomor 3592 dan 3593.

Perlu diketahui, dari penjelasan hadis tersebut menunjukkan bahwa hukum Islam sangat luwes. Tidak kaku. Sehingga jika suatu maslahat bila telah nyata kemaslahatannya dan telah sejalan dengan maksud Syari', maka menggunakan maslahat tersebut berarti telah memenuhi tujuan syariat meskipun tidak ada dalil khusus yang mendukungnya. Sebaliknya, bila tidak digunakan untuk menetapkan suatu hukum akan berarti melalaikan tujuan yang dimaksud oleh syariat. Padahal melalaikan maksud Syari' adalah perbuatan yang tertolak. Karena itu, menggunakan maslahat itu sendiri tidak menyalahi prinsip-prinsip syariat, bahkan sejalan dengan prinsip-prinsip syariat.

Lalu bagaimana pendapat ulama yang menolak Maslahah mursalah sebagai salah satu jalan istinbath hukum islam dalam menyelesaikan problematika ummat?. Para ulama ini memiliki pandangan bahwa suatu mashlahah terdapat petunjuk syara' yang dia membenarkannya atau disebut mu'tabarah, maka pada dasarnya ia telah termasuk dalam umumnya kias. Hal ini karena seandanya tidak ada petunjuk syara' yang membenarkannya, maka ia tidak mungkin disebut sebagai sebuah maslahat. Mengamalkan sesuatu yang di luar petunjuk syara' berarti mengakui akan kurang lengkapnya Alquran dan hadis-hadis nabi saw berserta risalah yang dibawanya.

Beramal dengan maslahat yang tidak medapatkan pengakuan tersendiri dari nas akan membawa kepada pengamalan hukum yang berlandaskan pada kehendak hati dan menurut hawa nafsu. Cara seperti ini tidak sesuai dengan tujuan-tujuan syara'. Keberatan al-Gazali untuk menggunakan istihsan dan maslahat mursalah pada dasarnya karena tidak ingin menetapkan hukum secara seenaknya (talazzuz) dan menetapkan syarat yang berat untuk penetapan hukum.

Menggunakan maslahat dalam berijtihad tanpa berpegang pada nash akan mengakibatkan munculnya sikap bebas dalam menetapka hukum yang dapat mengakibatkan seseoarng terzalimi atas nama hukum, karena menetapkan hukum dengan dugaan-dugaan yang tidak dapat dipastikan kebenarannya. Hal yang demikian jelas menyalahi 
prinsip penetapan hukum dalam Islam, yaitu la dharar wa la dhirar tidak boleh merusak dan tidak ada yang dirusak.

Seandainya dibolehkan berijtihad dengan maslahat yang tidak mendapat dukungan dari nas, niscaya hal itu akan menimbulkan terjadinya perbedaan hukum pada tiap wilayah, bahkan perbedaan pendapat perorangan dalam tiap perkara. maka hukum Islam akan berubah karena alasan berubahnya waktu dan berlainannya tempat berlakunya hukum Islam. Dalam kondisi tersebut, tidak akan ada kepastian hukum. Hal ini jelas tidak sejalan dengan prinsip syariat yang universal sepanjang zaman.

Argumentasi ulama yang menolak dan menerima maslahat sebagai dalil ijtihad dalam menetapkan hukum, jika diperhatikan secara seksama tampaknya tidak ada perbedaan yang prinsip. Golongan yang menerima ternyata tidak menerimanya secara mutlak dan serta merta tanpa ada persyaratan, justru mereka menetapkan sejumlah pesyaratan yang ketat. Demikian pula dengan golongan yang menolak, ternyata dasar penolakannya adalah karena mereka khawatir akan kemungkinan tergelincir pada kesalahan jika sampai menetapkan hukum dengan sekehendk hati dan berdasarkan hawa nafsu. Seandainya kekhawatiran ini dapat dihindarkan, misalnya telah ditemukannya garis kesamaan dengan prinsip utama, mereka juga akan menggunakan maslahat mursalah dalam berijtihad, sebagaimana imam Syafi'i sendiri melakukannya.

Berdasarkan gambaran di atas, dapat dipahami pada prinsipnya mayoritas ulama menerima maslahat sebagai salah satu dasar berijtihad dalam menetapkan hukum Islam, sekalipun terdapat perbedaan pendapat di antara para imam dan pengikut mazhab dalam menentukan syarat, penerapan, dan penempatannya.

\section{Maslahah mursalah dan Penerapannya dalam Menyikapi Problematika Umat}

Saat ini, permasalahan kehidupan manusia dari waktu ke waktu semakin kompleks dan beragam dan memerlukan kepastian hukum. Semisal permasalahan umat Islam dalam masaahah ekonomi seperti larangan dumping. Dumping merupakan sistem penjualan barang 
di pasar luar negeri dalam jumlah banyak dengan harga yang rendah dibandingkan dengan harga di dalam negeri dengan tujuan agar dapat menguasai pasar luar negeri dan menguasai harga komoditas tertentu. Menurut kamus istilah perdagangan internasional, dumping merupakan praktek penjualan produk di negara tujuan ekspor dengan harga di bawah harga normal atau harga produsennya yang bertujuan untuk menguasai pasar di luar negeri. ${ }^{31}$ Sesuai peraturan perdagangan internasional, praktek dumping dianggap sebagai praktek perdagangan yang tidak jujur dan dapat merugikan produsen produk saingan serta mengacaukan sistem pasar internasional.

Praktek dumping dalam menimbulkan kalah bersaingnya produk sejenis dalam negeri akibat harga produk impor tersebut jauh lebih murah dibandingkan harga produk sejenis yang ada dalam negara domestik, sehingga bukan saja potensial untuk menutup industry sejenis di dalam negeri tetapi juga pemutusan hubungan kerja (PHK) secara besar-besaran karena perusahaan dalam negeri harus menghemat biaya operasionalnya agar dapat bersaing dengan barang-barang impor yang harganya sangat murah.

Dalam hukum Islam, praktek dumping tidak ditemukan ayat maupun hadis yang melarangnya. ${ }^{32}$ Perdagangan luar negeri itu wajib bebas, tidak boleh ada yang membatasi dengan sesuatu apapun, termasuk pemerintah tidak boleh ikut campur dalam pelaksanaan atau penentuan kebijaksanaan perdagangan. Namun, tetap ada batasan-batasan yang tetap harus diperhatikan, yakni jangan sampai ada yang dirugikandalam perdagangan tersebut. Karena itulah, dengan pertimbangan untuk menciptakan kemaslahatan dan menghindarkan kemudharatan bagi masyarakat luas praktek dumping secara tegas dilarang dalam Islam.

Lalu bagaimana contoh mengurai masalah Maslahah mursalah selain dalam masalah ekonomi? Melakukan pencatatan perkawinan oleh etugas kantor urusan agama, dimana tujuan penulisan akta pernikahan ini adalah untuk keperluan sahnya gugatan perkawinan, nafkah, pembagian warisan, pembagian harta gono-gini di Indonesia

${ }^{31}$ Eddie Rinaldy. Kamus Istilah Perdagangan Internasional. (Jakarta: PT. Raja Grafindo Persada, 2000), h. 74.

${ }^{32}$ Tentang analisis hukum Islam terhadap dumping lihat Nita Anggraeni. "Dumping Dalam Perspektif Hukum Dagang Internasional dan Hukum Islam." Mazahib, Jurnal Pemikiran Hukum Islam. Vol. XIV, No. 2 (Desember 2015) 
merupakan bagian dari penerapan Maslahah mursalah yang dalam nash tidak disebutkan hukumnya. Dalam hal ini, pendekatan maslahah bisa menjadi acuan untuk kemudian mengambil konklusi hukum atas permasalahan yang timbul ditengah kehidupan masyarakat.

\section{Kesimpulan}

Dari uraian yang telah kami paparkan tentang Maslahah mursalah sejatinya ummat Islam memiliki ruang yang cukup luas untuk menggali hukum Islam dalam kehidupan sehari hari. Dalam hal ini, Islam merupakan agama yang tidak alergi dengan perubahan sistem sosial senyampang sistem tersebut tidak menimbulkan mafsadah dalam kehidupan bermasyarakat.

Dari sini, bahwa Islam sebagai "rahmatan lil-alamin" sepanjang masa tidak bisa terbantahkan. Karena dalam Islam, sejumlah terobosan hukum dalam memberikan solusi selalu tersedia. Dalam hal ini, Hukum Islam selalu hadir untuk menjaga kemaslahatan umat. Sehingga jika ada sebuah permasalahan atau problematika umat yang tidak ditemukan hukumnya secara pasti tentang suatu permasalahan baru yang baru muncul-baik dalam Al-quran maupun as-sunnah, para ulama membolehkan kepada umat islam terutama yang sudah ahli atau pakar dalam metode hukum Islam untuk menggunakan maslahah sebagai acuan dalam menyikapi problematika umat. 


\section{Daftar Pustaka}

Abu Zahrah, Muhammad, Tarikh al-Mazahib al-Islamiyh, al- Qahirah: Dar al-Fikr al-'Arabi, t.th.

Ibn al-Manzûr, 1972, Lisân al-Arabal-Muhît, Beirut: Dâr al-Fikr.

Rahmad Syafi'i, 2007, Ilmu Usul Figh, Bandung:Pustaka Setia.

Abdul Aziz Dahlan dkk, 2001, Ensiklopedi Hukum Islam, Jilid IV, Jakarta: PT Ichtiar Baru van Hoeve.

Amir Syarifuddin, 2009, Ushul Figh, Jilid II, Jakarta: Kencana.

Islam, M. H. (2018). ISLAMIC LAW IN INDONESIA (Tradition, Thought, Political Law and Legal Products). As-Syari'ah: Jurnal Hukum Islam, 4(1), 31-50

Njm al-Din al-Tufi, 1993, Risalah fi Ri'ayah al-Maslahah, Libanon: alDar al Masdariyyah al-Lubnaniyyah.

Abu Hamid Muhammad Ibn Muhammad al-Gazali, 1993, al-Mustasfa, Bairut: Dar al-Kutub al 'Ilmiyyah.

https:/muhammadunaslam.wordpress.com/2010/06/21/maslahahdalam-islam/. diakses pada Tanggal 10 Februari 2018.

Muhammad Abu Zahrah, 1994, Ushul Figh, Cet. II, Terj. Saefullah Ma'shum, dkk.,Jakarta, PT Pustaka Firdaus.

Ma'ruf Amin, 2011, Fatwa dalam Sistem Hukum Islam, Jakarta: elSAS.

Abu Daud, Shahih Sunan Abu Dawud, 1998, Jilid 2, Riyad: Maktabah al-Ma'arif.

Nasrun Haroen, 1997, ushul fiqih, Ciputat : PT Logos Wacana Imu.

Abd al-Karim Zaidan, 1987, al-Wajiz fi Usul al-Fiqh, Bairut: Muassasah al-Risalah.

Abd al-Wahhab Khallaf, Ilm Usul al-Fiqh wa Khulasah Tarikh al-Tasyri', Mesir: Matba'ah al-Madani, t.th.

Eddie Rinaldy, 2000, Kamus Istilah Perdagangan Internasional, Jakarta: PT. Raja Grafindo Persada.

Badr al-Din Muhammad bin "Abdullah al-Zarkasyi, 1994, al-Bahr alMuhit fi Usul al-Fiqh, Juz VIII, t.tp.: Dar al-Kutaibi. 